\title{
EFEKTIFITAS FISIOTERAPI DADA DAN BATUK EFEKTIF PASCA NEBULASI TERHADAP BERSIHAN JALAN NAFAS PADA PASIEN TB PARU DI RSU TANGERANG
}

\author{
Parta Suhanda*, Maman Rusmana*
}

\begin{abstract}
Abstrak
Penyakit Tuberculosis (TBC) dilaporkan meningkat secara drastis pada dekade terakhir ini di seluruh dunia termasuk di Indonesia. Penyakit ini biasanya banyak terjadi pada negara berkembang atau yang mempunyai tingkat sosial ekonomi menengah ke bawah. Tuberculosis (TBC) merupakan penyakit infeksi penyebab kematian dengan urutan atas atau angka kematian (mortalitas) tinggi, angka kejadian penyakit (morbiditas), diagnosis dan terapi yang cukup lama, masalah yang sering terjadi adanya penumpukan secret pada jalan nafas, upaya yang dilakukan perawat adalah melakukan fisioterapi dada dan melatih batuk efektif, kedua tindakan ini biasa dilakukan, namun penelitian terkait efektifitas tindakan tersebut masih kurang. Tujuan penelitian untuk mengetahui manakah yang lebih besar pengaruhnya terhadap bersihan nafas pasca nebulasi antara sebelum dan sesudah dilakukan fisiterapi dada atau batuk efektif. Jenis penelitian yang digunakan dalam penelitian ini adalah menggunakan rancangan Quesi Eksperimen. jumlah sampel 30 orang tiap kelompok, cara pengambilan sampel consecutive sampling. Analisis penelitian menggunakan uji $\mathrm{t}=$ independen dan $\mathrm{t}$-dependen. Hasil penelitian ada perbedaan yang signifikan $\mathrm{p}=0,000$ sebelum dan sesudah dilakukan tindakan fisioterafi dada dan batuk efektif terhadap bersihan jalan nafas pasien TBC Paru, namun kedua tindakan tersebut tidak menunjukan perbedaan yang signifikan antara tindakan fisioterafi dada dan batuk efektif terhadap bersihan jalan nafas pasca nebulasi $p$ value $=0,564 \alpha=0,05$.
\end{abstract}

Kata Kunci : Bersihan jalan nafas, fisioterafi dada, batuk efekti

*Poltekkes Kemenkes Banten 


\section{Pendahuluan}

Penyakit Tuberculosis (TBC) belakangan ini dilaporkan meningkat secara drastis ini di seluruh dunia termasuk di Indonesia dan merupakan penyakit infeksi penyebab kematian dengan urutan atas atau angka kematian (mortalitas) tinggi, angka kejadian penyakit (morbiditas), diagnosis dan terapi yang cukup lama, bahkan setiap empat menit sekali satu orang meninggal akibat TBC di Indonesia. (Zulkifli, 2006). Indonesia termasuk penyumbang kasus TBC terbesar ke 3 di dunia, dengan jumlah penderita per tahunnya adalah 587.000 orang, (WHO, Jun 2007)

Pasien TB Paru biasanya mengalami gangguan bersihan jalan nafas (penumpukan secret), pengobatan secara medis tidak bisa menyembuhkan secara tuntas $100 \%$, untuk mengencerkan mukus biasanya diberikan inhalasi atau nebulizer, melalui latihan fisioterapi dada, antara lain: perkusi, vibrasi, drainase, nafas dalam dan batuk efektif. Upaya ini dapat memudahkan pengeluaran sekret sehingga jalan nafas menjadi lancar. (Aditama, 2003)

Tindakan fisioterapi dada dan batuk efektif biasanya sering dilakukan oleh perawat, sebagai tindakan mandiri, namun dari kedua tindakan ini, efektifitasnya belum diketahui dalam membebaskan jalan nafas. Berdasarkan uraian diatas peneliti merasa tertarik melakukan penelitian mengenai "Efektifitas Fisioterapi dada dan batuk efektif pasca nebulasi terhadap bersihan jalan napas pada pasien TBC Paru di ruang RSU Tanggerang”.

Tujuan penelitian ini untuk mengetahui efektifitas tindakan fisioterapi dada dan batuk efektif pasca nebulasi terhadap bersihan jalan nafas pada pasien TB Paru di RSU

\section{Metode Penelitian}

Penelitian ini menggunakan desain kuasieksperimen. yaitu satu kelompok pasien dilakukan tindakan fisioterapi dada, dan satu kelompok dilakukan tindakan batuk efektif, kemudian diukur bersihan jalan nafasnya sebelum dan sesudah tindakan, . Populasi penelitian ini adalah pasien TB Paru yang dilakukan tindakan nebulasi. Sampel adalah pasien TB Paru yang dilakukan tindakan nebulasi berjumlah 60 orang. Pengambilan sampel dengan cara consecutive sampling. Tempat penelitian di Ruang IGD dan ruang perawatan penyakit dalam RSU Tangerang pada bulan Mei - Agustus 2012. Pengolahan data menggunakan uji $t$ dependen dan uji t-independen. 


\section{Hasil Penelitian}

Setelah data diolah dengan menggunakan perangkat lunak, maka selanjutnya hasil penelitian disajikan dalam bentuk table. Data penelitian ini terbagi menjadi hasil analisa univariat dan bivariat.

Tabel 1

Distribusi Frekuensi Pasien TBC Paru yang menjalani fisioterapi dada Pasca Nebulasi berdasarkan Usia di RSU Tangerang

\begin{tabular}{|l|c|c|}
\hline \multicolumn{1}{|c|}{ Usia Responden } & $\begin{array}{c}\text { JUMLAH } \\
\text { RESPONDEN }\end{array}$ & $\%$ \\
\hline Pra sekolah ( < 6 tahun) & 3 & $10 \%$ \\
\hline Sekolah 6- 18 tahun & 9 & $30 \%$ \\
\hline Dewasa $19-50$ tahun & 14 & $47 \%$ \\
\hline Lanjut usia $>50$ tahun & 4 & $13 \%$ \\
\hline TOTAL & 30 & $100 \%$ \\
\hline
\end{tabular}

Berdasarkan tabel 1, diketahui sebagian besar pasien TBC Paru yang menjalani fisioterapi dada pasca nebulasi berusia 19 50 tahun sebanyak 14 orang (47\%).

Tabel 2

Distribusi Frekuensi Usia Pasien TBC Paru yang menjalani Batuk Efektif Pasca Nebulasi di RSU Tangerang

\begin{tabular}{|l|c|c|}
\hline \multicolumn{1}{|c|}{ Usia Responden } & $\begin{array}{r}\text { JUMLAH } \\
\text { RESPONDEN }\end{array}$ & PERSENTASE \\
\hline Pra sekolah ( $<6$ tahun) & 2 & $7 \%$ \\
\hline Sekolah 6- 18 tahun & 4 & $13 \%$ \\
\hline Dewasa $19-50$ tahun & 16 & $53 \%$ \\
\hline Lanjut usia > 50 tahun & 8 & $27 \%$ \\
\hline TOTAL & 30 & $100 \%$ \\
\hline
\end{tabular}

Berdasarkan tabel 2, diketahui sebagian besar pasien TBC Paru yang menjalani batuk efektif pasca nebulasi berusia $19-50$ tahun sebanyak 16 orang (53\%).

Tabel 3

Distribusi Frekuensi Bersihan jalan nafas Pasien TBC Paru sebelum menjalani Batuk Efektif Pasca Nebulasi di RSU Tangerang

\begin{tabular}{|l|l|c|c|}
\hline No & Kondisi Jalan Nafas & JML & \% \\
\hline 1. & $\begin{array}{l}\text { Bersih } \geq 2 \text { gejala } \\
\text { normal)=3 }\end{array}$ & 2 & $7 \%$ \\
\hline 2. & $\begin{array}{l}\text { Tidak Bersih (Bunyi } \\
\text { nafas ronki, frekuensi } \\
\text { nafas tidak normal, } \\
\text { nafas sesak)=0 }\end{array}$ & 22 & $73 \%$ \\
\hline 3. & $\begin{array}{l}\text { Tidak bersih ( salah } \\
\text { satu dari ketiga } \\
\text { gejala normal) =1 }\end{array}$ & 6 & $20 \%$ \\
\hline & Jumlah : & 30 & \\
\hline
\end{tabular}

Berdasarkan tabel 3, diketahui sebagian besar pasien TBC Paru sebelum menjalani batuk efektif pasca nebulasi jalan nafasnya tidak bersih sebanyak 22 orang (73\%).

Tabel 4

Distribusi Frekuensi Bersihan jalan nafas Pasien TBC Paru setelah menjalani Batuk Efektif Pasca Nebulasi di RSU Tangerang

\begin{tabular}{|l|l|c|c|}
\hline No & \multicolumn{1}{|c|}{$\begin{array}{c}\text { Kondisi Jalan } \\
\text { Nafas }\end{array}$} & JML & \% \\
\hline 1. & $\begin{array}{l}\text { Bersih } \geq 2 \text { gejala } \\
\text { normal) }=3\end{array}$ & 15 & $50 \%$ \\
\hline 2. & $\begin{array}{l}\text { Tidak Bersih (Bunyi } \\
\text { nafas ronki, } \\
\text { frekuensi nafas tidak } \\
\text { normal, nafas sesak) } \\
=0\end{array}$ & 7 & $24 \%$ \\
\hline 3. & $\begin{array}{l}\text { Tidak bersih ( salah } \\
\text { satu dari ketiga } \\
\text { gejala normal)=1 }\end{array}$ & 8 & $26 \%$ \\
\hline & \begin{tabular}{l} 
Jumlah : \\
\hline
\end{tabular} \\
\hline
\end{tabular}


Berdasarkan tabel 4, diketahui sebagian besar pasien TBC Paru setelah menjalani batuk efektif pasca nebulasi jalan nafasnya menjadi bersih sebanyak 15 orang (50\%).

\section{Tabel 5}

Distribusi Frekuensi Bersihan jalan nafas Pasien TBC Paru sebelum menjalani Fisioterafi Dada Pasca Nebulasi di RSU Tangerang

\begin{tabular}{|c|c|c|c|}
\hline No & Kondisi Jalan Nafas & JML & $\%$ \\
\hline 1. & $\begin{array}{l}\text { Bersih }(\geq 2 \text { gejala } \\
\text { normal })=3\end{array}$ & 0 & $0 \%$ \\
\hline 2. & $\begin{array}{l}\text { Tidak Bersih (Bunyi } \\
\text { nafas ronki, frekuensi } \\
\text { nafas tidak normal, } \\
\text { nafas sesak) }=0\end{array}$ & 22 & $\begin{array}{l}73 \\
\%\end{array}$ \\
\hline 3. & $\begin{array}{l}\text { Tidak bersih ( salah } \\
\text { satu dari ketiga gejala } \\
\text { normal) }=1\end{array}$ & 8 & $\begin{array}{l}27 \\
\%\end{array}$ \\
\hline & Jumlah : & 30 & \\
\hline
\end{tabular}

Berdasarkan tabel 5, diketahui sebagian besar pasien TBC Paru sebelum menjalani fisioterafi dada pasca nebulasi jalan nafasnya tidak bersih sebanyak 22 orang $(73 \%)$.

Tabel 6

Distribusi Frekuensi Bersihan jalan nafas Pasien TBC Paru setelah menjalani Fisioterafi Dada Pasca Nebulasi di RSU Tangerang

\begin{tabular}{|l|l|c|c|}
\hline No & Kondisi Jalan Nafas & JML & $\%$ \\
\hline 1. & $\begin{array}{l}\text { Bersih } \geq 2 \text { gejala } \\
\text { normal)=3 }\end{array}$ & 13 & $43 \%$ \\
\hline 2. & $\begin{array}{l}\text { Tidak Bersih (Bunyi } \\
\text { nafas ronki, frekuensi } \\
\text { nafas tidak normal, } \\
\text { nafas sesak)=0 }\end{array}$ & 3 & $10 \%$ \\
\hline 3. & $\begin{array}{l}\text { Tidak bersih ( salah } \\
\text { satu dari ketiga } \\
\text { gejala normal)=1 }\end{array}$ & 14 & $47 \%$ \\
\hline & Jumlah : & 30 & \\
\hline
\end{tabular}

Berdasarkan tabel 6, diketahui sebagian besar pasien TBC Paru setelah menjalani fisioterafi dada pasca nebulasi jalan nafasnya bersih sebanyak 13 orang (43\%).

Tabel 7

Hasil Uji Statistik Perbedaan Bersihan Jalan Nafas Pasien TB Paru sebelum dan setelah diberi tindakan fisioterafi dada Pasca Nebulasi di RSU Tangerang

\begin{tabular}{|l|l|c|c|}
\hline \multicolumn{1}{|c|}{ Variabel } & Mean & SD & $\begin{array}{c}\text { P } \\
\text { value }\end{array}$ \\
\hline Bersihan Jalan & & & \\
Nafas & 0,27 & 0,450 & 0,000 \\
*Sebelum & 1,70 & 1,088 & \\
*Setelah & & & \\
\hline
\end{tabular}

Dari tabel diatas terlihat bahwa dari 30 responden rata-rata bersihan jalan nafas sebelum fisioterafi dada adalah 0,27 dengan SD 0,450 dan setelah fisioterafi dada adalah 1,70 dengan SD 1,088. Dari uji statistik diperoleh nilai P 0,000. Dengan demikian pada $\alpha$ 5\% maka secara statistik dapat disimpulkan terdapat perbedaan yang bermakna rata-rata bersihan jalan nafas pada pasien TBC Paru sebelum dan setelah dilakukan fisioterafi dada pasca nebulasi.

Tabel 8

Hasil Uji Statistik Perbedaan Bersihan Jalan Nafas Pasien TB Paru sebelum dan setelah diberi tindakan Batuk Efektif

\begin{tabular}{|l|l|c|c|}
\hline \multicolumn{1}{|c|}{ Variabel } & mean & SD & $\begin{array}{c}\text { P } \\
\text { value }\end{array}$ \\
\hline $\begin{array}{l}\text { Bersihan Jalan Nafas } \\
\text { * Sebelum }\end{array}$ & 0,27 & 0,521 & 0,000 \\
*Setelah & 1,53 & 1,137 & \\
\hline
\end{tabular}


Dari tabel diatas terlihat bahwa dari 30 responden rata-rata bersihan jalan nafas sebelum fisioterafi dada adalah 0,27 dengan SD 0,521 dan setelah fisioterafi dada adalah 1,53 dengan SD 1,137. Dari uji statistik diperoleh nilai $\mathrm{P}$ 0,000. Dengan demikian pada $\alpha 5 \%$ maka secara statistik dapat disimpulkan terdapat perbedaan yang bermakna rata-rata bersihan jalan nafas pada pasien TBC Paru sebelum dan setelah batuk efektif pasca nebulasi.

\section{Tabel 9}

Hasil Uji Statistik Perbedaan Bersihan Jalan Nafas Pasien TB Paru yang diberi tindakan fisioterafi dada dan batuk efektif setelah dilakukan nebulasi di RSU Tangerang

\begin{tabular}{|c|c|c|c|}
\hline Variabel & Mean & SD & $\begin{array}{c}P \\
\text { value }\end{array}$ \\
\hline $\begin{array}{l}\text { Bersihan Jalan Nafas } \\
\text { - Tindakan } \\
\text { Fisioterafi Dada }\end{array}$ & 1,70 & 1,088 & 0,564 \\
\hline $\begin{array}{l}\text { - Tindakan Batuk } \\
\text { efektif }\end{array}$ & 1,53 & 1,137 & \\
\hline
\end{tabular}

Dari tabel diatas terlihat bahwa dari 30 responden rata-rata bersihan jalan nafas adalah 1,70 dengan SD 1,088 pada kelompok yang dilakukan fisioterafi dada. Dari uji statistik diperoleh nilai P 0,564. Dengan demikian pada $\alpha 5 \%$ maka secara statistik tidak terdapat perbedaan rata-rata bersihan jalan nafas pada kelompok yang dilakukan fisioterafi dada dan kelompok batuk efektif pasca dilakukan nebulasi pada pasien TBC Paru.

\section{Pembahasan}

Berdasarkan hasil penelitian, diketahui bahwa ada perbedaan yang signifikan sebelum dan sesudah tindakan fisioterafi dada dan batuk efektif terhadap gian besar bersihan jalan nafas pasca nebulasi $(\mathrm{p}=0,000)$. Hal ini menunjukan bahwa kedua tindakan tersebut sangat berguna untuk membersihkan jalan nafas pasien. Namun kalau dibandingkan kedua tindakan tersebut tidak ada yang lebih efisien $(p=0,564)$

Menurut Taskhin (2001), fisioterafi dada (Vibrasi) secara umum dilakukan bersamaan dengan clapping. Vibrasi dengan kompresi dada dapat menggerakkan sekret ke jalan nafas yang besar sedangkan perkusi melepaskan/melonggarkan sekret. Vibrasi dapat dilakukan hanya pada waktu pasien mengeluarkan nafas. Pasien diminta bernafas dalam dan kompresi dada dan vibrasi dilaksanakan pada puncak inspirasi dan dilanjutkan sampai akhir ekspirasi. Vibrasi dilakukan dengan cara meletakkan tangan bertumpang tindih pada dada kemudian dengan dorongan bergetar.

Hasil yang diperoleh melalui fisioterapi dada, bersihan nafas pasca nebulasi dari $0 \%$ yang bersih menjadi $43 \%$ dibandingkan sebelum dan sesudah dilakukan fisoterapi 
dada. Dengan demikian ada perbedaan hasil sebelum dan setelah diberikan fisioterapi dada. Bersihan jalan nafas sesudah dilakukan fisioterapi dada pada pasien TBC paru, yaitu ada peningkatan pasien dengan jalan nafas menjadi lebih bersih sebesar $43 \%$.

Perbedaan hasil bersihan nafas sebelum dan setelah diberikan fisoterapi dada disebabkan oleh cara dan fungsi kerja fisioterapi dada lebih optimal dibandingkan dengan cara biasa (manual). Hal ini diperkuat oleh teori fitzgerald (2001), fisioterapi dada adalah salah satu dari pada fisioterapi yang sangat berguna bagi penderita penyakit respirasi baik yang bersifat akut maupun kronis. Fisioterapi dada ini walaupun caranya kelihatan tidak istimewa tetapi ini sangat efektif dalam upaya mengeluarkan sekret dan memperbaiki ventilasi pada pasien dengan fungsi paru yang terganggu.

Fisioterapi dada ini dapat digunakan untuk pengobatan dan pencegahan pada penyakit paru obstruktif menahun, penyakit pernafasan restriktif termasuk kelainan neuromuskuler dan penyakit paru restriktif karena kelainan parenkim paru seperti fibrosis dan pasien yang mendapat ventilasi mekanik. Namun dengan cara menggunakan fisoterapi dada, pasien belum tentu bebas dari kontra indikasi yang bersifat mutlak seperti kegagalan jantung, status asmatikus, renjatan dan perdarahan masif, sedangkan kontra indikasi relatif seperti infeksi paru berat, patah tulang iga atau luka baru bekas operasi, tumor paru dengan kemungkinan adanya keganasan serta adanya kejang rangsang.

Analisa peneliti, fungsi fisioterapi dada dengan vibrasi sangat efektif bagi pasien paru untuk mengeluarkan secret dan memperbaiki ventilasi pada pasien dengan fungsi paru yang terganggu. Melalui fisioterapi dada, pasien juga mendapatkan manfaat yang lebih dibandingkan dengan cara manual, salah satunya adalah nafas menjadi lebih ringan (memperkecil kemungkinan asma berkelanjutan) dan menurunkan tingkat stress atau gangguan emosi yang dapat menjadi pencetus serangan asma dan juga dapat memperberat serangan asma. Penderita TBC paru atau asma berat karena ganguan stress dan emosi perlu diberikan arahan untuk menyelesaikan masalah, karena jika hal ini terus berlanjut maka penderita asma belum bias diatasi.

Menurut Nanda (2005), bersihan jalan napas adalah cara membersihkan sekresi atau obstruksi dari saluran pernafasan untuk menjaga bersihan jalan napas, sedangkan Fisioterapi dada adalah salah satu dari pada fisioterapi yang sangat berguna bagi penderita penyakit respirasi baik yang bersifat akut maupun kronis. Dengan demikian ada pengaruh yang signifikan dari 
kedua variable tersebut, dimana menurut teori salah satu cara membersihkan sekresi dari saluran pernapasan adalah dengan menggunakan fisioterapi dada. Sehingga jika teknik fisioterapi dada ini terus ditingkatkan penggunaanya bagi penderita TBC paru, maka kemungkinan bersihan jalan nafas pun meningkat menjadi lebih bersih dari sebelumnya, seperti nafas menjadi teratur dan mengurangi batuk tidak efektif. Dampak positif lainnya dari penggunaan fisioterapi dada adalah pasien menjadi lebih mudah tidurnya dan pola makan pasien menjadi lebih teratur.

Analisa penulis, tujuan pokok fisioterapi pada penyakit TBC paru adalah mengembalikan dan memelihara fungsi otototot pernafasan dan membantu membersihkan sekret dari bronkus dan untuk mencegah penumpukan sekret, memperbaiki pergerakan dan aliran sekret. Sehingga fungsi dan pengaruh fisioterapi dada terhadap bersihan jalan nafas lebih efektif dan optimal dengan hasil penelitian ada perbedaan yang nyata sebelum dan sesudah dilakukan fisoterapi dada.

Batuk efektif juga merupakan tindakan yang sangat bermanfaat dimana menunjukan berbedaan yang signifikan antara sebelum dan setelah dilakukan tindakan batuk efektif. Hasil perbedaan tersebut menunjukan bahwa peranan batuk efektif dan fisoterapi dada pada pasien TBC paru sangat membantu mengurangi bersihan jalan nafas tidak bersih akibat sesak nafas, dan adanya kesulitan berbicara. Dengan demikian pengaruh bersihan jalan nafas sesudah dilakukan fisoterapi dada hasilnya lebih baik dibandingkan sebelum dilakukan fioterapi dada.

Tindakan fisioterafi dada dan batuk efektif keduanya dapat dilakukan untuk mengeluarkan sekret pada jalan nafas pasien TBC Paru. Namun kedua tindakan ini tidak ada perbedaan yang signifikan dalam membantu mengurangi bersihan jalan nafas, meskipun secara rerata fisioterafi dada lebih tinggi sedikit, namun perbedaan yang tidak bermakna secara statistik. Kedua tindakan ini pada pelaksanaannya dapat dilakukan secara bersamaan sehingga hasilnya maksimal.

\section{Simpulan}

Kesimpulan dalam penelitian ini adalah :

1. Hasil analisis univariat, sebagian besar bersihan jalan nafas sebelum dilakukan fisioterapi dada pada pasien TBC paru adalah bersih (7\%). Sedangkan sesudah dilakukan fisioterapi dada pada pasien TBC paru adalah bersih menjadi (50\%).

2. Hasil analisis univariat, sebagian besar bersihan jalan nafas sebelum dilakukan batuk efektif pada pasien TBC paru adalah bersih $(0 \%)$. Sedangkan sesudah 
dilakukan batuk efektif pada pasien TBC paru adalah bersih menjadi (43\%).

3. Hasil uji statistik diperoleh nilai $\mathrm{p}=$ 0,000, sehingga dapat disimpulkan ada berbedaan yang signifikan bersihan jalan nafas pasca nebulasi antara sebelum dan sesudah dilakukan fisoterapi dada dan batuk efektif pada pasien TBC Paru di RSU Tangerang.

4. Hasil Uji statistik tidak ada perbedaan yang signifikan bersihan jalan nafas sesudah dilakukan fisoterapi dada dan batuk efektif $\mathrm{p}=0,5564$, hal ini menunjukan bahwa kedua tindakan fisioterafi dada dan batuk efektif samasama baik dapat dilakukan untuk membersihkan jalan nafas.

\section{Daftar Pustaka}

Aditama, T. Y, 2003. Terapi Tuberkulosis dengan Fixed Dose Combination (FDC).Vohune II. Jakarta:RS Persahabatan.

Alsagaff, $H$ dan Abdul Mukty. 2006. Infcksi Tuberkulosis Paru.Surabaya :University Press.

Antonio. 2008. DOTS Sebagai Strategj Baru daiam Penanggulangan Tuberkulosis dan Pelaksanaanya di Puskesmas.Surabaya: Medika.

Arikunto, S. 2006. Prosedur Penelitian Suatu Pendekatan Praktik. Edisi Revisi 6. Jakarta PT. Rineka Cipta.
Fitzgerald M, 2001 Acute Asthma Clinical Review. Exstract from Clinical Evidence BMJ.

Jenne JW, Tashkin DP, 2001: Beta Adrenergic Agonists: in Weiss EB, Stein M: Bronchial Asthma, Mechanism and Therapeutics. Little Brown and Comp. Boston Toronto London 3Ed.

Nanda, H.A. 2005. Faktor Faktoryang Mempengaruhi Penderita TB Paru Putus Berob di RSUD dr.Soebandi Jember.: UNEJ

Smeltzer, S.C \& Bare, B.G. 2001. Buku Ajar Keperawatan Medikal Bedah Brunner dan Suddarth.Volume 3. Jakarta : EGC.

Sugiyono. Metode Penelitian Kuantitatif dan Kualitatif Dan R \& D. cetakan ke 7. CV Alfabeta. Bandung. 2009.

Zulkifli Amin, Asril Bahar, 2006. Tuberkulosis Paru, Buku Ajar Ilmu Penyakit Dalam, Jakarta: UI 